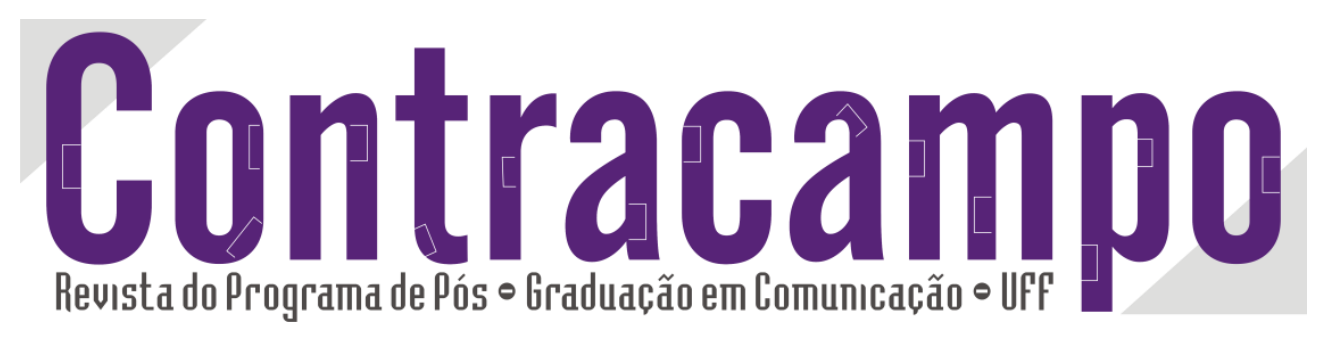

\title{
A poesia do real em Paranoid Park
}

\author{
The poetry of the real in Paranoid Park
}

Bruno Costa

brunocscosta@gmail.com

Doutor em comunicação pela PUC-RS, professor assistente da PUC Minas.

Ao citar este artigo, utilize a seguinte referência bibliográfica

COSTA, Bruno. A poesia do real em Paranoid Park. In: Revista Contracampo, v. 24, n. 1, ed. julho, ano 2012. Niterói: Contracampo, 2012. Pags: 105-119.

\section{PPGCOM UFF}

\section{Edição 24/2012}

Temáticas diversas

Contracampo

Niterói (RJ), v. 24, n. 1, jul./2012.

e-ISSN 2238-2577
Enviado em: 07 de mar. de 2012

Aceito em: 17 de abr. De 2012 www.uff.br/contracampo

A Revista Contracampo é uma revista eletrônica do Programa de PósGraduação em Comunicação da Universidade Federal Fluminense e tem como objetivo contribuir para a reflexão crítica em torno do campo midiático, atuando como espaço de circulação da pesquisa e do pensamento acadêmico. 


\section{Resumo}

Este artigo visa repensar o realismo cinematográfico pesando alterações nos registros ficcionais que se habilitam a falar sobre o real. Para tanto, selecionou-se o filme de Gus Van Sant, Paranoid Park (2007), como exemplar privilegiado sobre várias reflexões sobre as estratégias representativas de viés realista porque ele acusa uma renovação nesta estética. Esta renovação passa por uma série de questionamentos e inversões e remete-se fortemente ao contemporâneo, por exemplo, ao questionar o pacto biográfico, recusar a teleologia e aceitar o caráter fragmentado e descontínuo da vida. Estas escolhas conversam ainda com o momento pós-moderno e indicam para uma nova relação entre sujeito e objeto que gera uma abordagem lateral, metafórica ou poética que enfrenta a pretensão revelatória de vários realismos.

Palavras-chave: cinema; realismo; Paranoid Park.

\section{Abstract}

This article seeks to rethink the cinematic realism weighing changes to the records that are enabled to talk about the real. To this end, we chose Gus Van Sant's Paranoid Park (2007), as a prime example of many reflections on the strategies of the realistic representations because he accuses a renewal in this aesthetic. This renewal goes through a series of questions and inversions and is strongly related to the contemporary era, for example, by questioning the biographical pact, by refusing to accept teleology and by accepting the fragmented and discontinuous nature of life. These choices talk with the postmodern moment and point to a new relationship between subject and object that generates a lateral approach, metaphorical or poetic that opposes itself to several revelatory realisms.

Keywords: cinema; realism; Paranoid Park. 
estética realista no cinema se caracteriza, muitas vezes, pela abordagem direta e chocante. Aventar o acesso à realidade, portanto, passa pela tentativa de incitar o choque, como no caso da estética de choque de real presente no cinema brasileiro contemporâneo. Em outros estilos realistas a impressão de realidade procura apagar as marcas mediadoras evitando ao máximo salientar o artifício. Este caminho tem sido adotado desde a escola neorrealista italiana e ainda encontra abrigo no cinema dos irmãos Dardenne e também de Bruno Dumont. Uma terceira tendência busca na precariedade técnica uma nova forma de autenticidade, apelando para a imagem suja ou para a câmera instável como forma de emular um registro amador. Esta direção, a mais recente, faz uso da familiaridade da estética amadora típica dos vídeos YouTube o caminho para angariar o efeito de realidade e pode ser vista tanto em filmes de terror mais recentes como Rec (Jaume Balagueró, Paco Plaza, 2007) como em thrillers como Cloverfield (Matt Reeves, 2008). Mais produtivo, entretanto, do que delimitar um modo ótimo de reproduzir a realidade é investigar o potencial hermenêutico por trás das escolhas técnicas e estéticas que conformam os diversos estilos realistas.

Em Paranoid Park muitas das escolhas dialogam criticamente com os modos de representação da realidade e tentam conformar uma nova estética realista. Neste processo, ilumina-se uma série de posições marcadas que fazem ver um autor. Falamos da presença marcada do autor para destacarmos como, por meio de certas opções técnicas, estéticas e narrativas, estabelece-se uma singularidade que distingue a obra. Será por meio da análise destas escolhas que poderemos ver a marca específica do jogo entre fictício e imaginário no filme em questão. Há, portanto, a necessidade de explicitar mais detalhadamente quais concepções imaginárias são aventadas nas decisões do autor. Em primeiro lugar, sobressai o confronto com a estrutura de enredo tradicional, aquela que prevê um nó e um consequente desenlace para a trama. O filme a todo o tempo resiste a esta moldura e evita ao máximo relacionar o desenvolvimento da narrativa à resolução da intriga. Um segundo confronto estabelece-se com a ilusão de ubiquidade da narrativa cinematográfica. Neste embate, Paranoid Park abandona a pretensão de apresentar contínuos vantage points em busca de um olhar marcadamente subjetivo. Uma terceira frente é aquela que opõe vida e narrativa, ou seja, ataca-se a coincidência 
entre a vivência e sua representação dramática. Oposta à narrativa, a vida parece especialmente sem sentido e é esta falta de sentido imanente que vai ser perseguida em Paranoid Park como forma de estabelecer um contato diferenciado com o real. Todos estes caminhos remetem a um confronto mais geral com as significações imaginárias cinematográficas instituídas no que tange à criação de realidades.

De imediato, esta tentativa remete à construção de um novo código realista, um código em consonância com o pós-modernismo, seja por pressupor uma alta reflexividade das práticas representacionais, seja por colocar-se como concorrente às outras formas de representação realistas vigentes ou, ainda, por promover (a seu modo) uma guinada ao sujeito. Para participar desta disputa pelo real, o filme de Van Sant usa de técnicas e artifícios que já vinham sendo construídos em obras anteriores do diretor, especialmente em Elefante (2003) e Last days (2005). No primeiro, perante o grande evento midiático recoberto de signos e significados, o massacre da escola secundária de Columbine, há uma resistência à explicação causal. Os protagonistas do tiroteio, olhados pela câmera de Van Sant, não se mostram particularmente excepcionais e mesmo as ações que os levaram ao crime não parecem destacar-se da ordinariedade do cotidiano. Já em Last days, uma biografia dos últimos dias da vida de Kurt Cobain, o confronto imaginário põe em cheque a ilusão biográfica. No filme, a morte deixa de ser um evento que realiza uma montagem da vida, ela é apenas o fato derradeiro de uma existência na qual parece ser difícil achar os elos de causalidade.

Em Paranoid Park estes movimentos anteriores ajudam a conformar a estética realista. Como em Elefante, há um grande evento que cerca a narrativa, desta vez o assassinato acidental cometido pelo protagonista Alex. Este evento, no entanto, não parece ser o centro para o qual irradia a economia dramática da história. A sua sombra, também como no filme sobre o massacre de Columbine, cobre toda a narrativa, sem, contudo, ser um polo de atração que ressignifica os vários pequenos incidentes do cotidiano. A resistência ao biográfico, exercitada em Last days, toma a forma da apresentação de diversas ações paralelas ao grande evento. Cada uma delas fornece uma peça de um grande quebra-cabeça que não necessariamente se mostrará completo no final do filme.

O valorizar da experiência pessoal e do retrato parcial dialogam também com uma tendência progressivamente crescente na cultura contemporânea, aquela 
denominada habilmente por Sarlo (2007) como guinada subjetiva. Essa guinada ao sujeito só será possível dentro de um movimento mais amplo de contestação a uma concepção excessivamente positiva e positivante da verdade e, portanto, ela marca tanto uma revalorização do testemunho e da experiência narrada como inclui também novos sujeitos que estiveram alijados do discurso. A emergência de novos lugares de enunciação deixa ainda mais evidente a desfragmentação do discurso de verdade (o antigo logos que já na Grécia clássica foi disputado e clamado pela filosofia e desde então tinha sido reservado prioritariamente para a ciência), o testemunho e as pequenas histórias entram em combate direto com uma concepção histórica que sempre preferiu os grandes relatos e os documentos. A potência do testemunho mostra-se especialmente na reconstituição de grandes eventos traumáticos nos quais o distanciamento natural dos métodos historiográficos tradicionais parece deixar de fora parte importante do que aconteceu.

\section{A linguagem da realidade em Paranoid Park}

Todas estas tendências encontram uma forma no filme em questão, o evento traumático pede uma abordagem subjetiva e a renovação do realismo passa pela criação de novos lugares de enunciação. Há, portanto, uma tentativa de encontrar uma linguagem que fale com a realidade contemporânea, com a fragmentação, com a subjetividade marcada e com a resistência ao teleológico, todos traços típicos do pósmodernismo. Como então se forma a linguagem da realidade em Paranoid Park? Lembremos de Pasolini (2005) que elegia o plano sequência como a técnica especialmente equipada para narrar a vida, vide a coincidência deste com a subjetividade associada ao olhar humano. Há de se ponderar, entretanto, que parte do poder do plano sequência estava atrelada à transparência da imagem técnica. Hoje em dia qualquer transparência é vista com desconfiança, mesmo os documentários fazem 
questão de trazer para a sua diegese os processos de produção da ilusão naturalística ${ }^{1}$. Paralelamente, os ambientes hipermediados são integrados nas práticas cotidianas, oferecendo, deste modo, um novo caminho para narrar a realidade. A ausência de planos sequências em Paranoid Park, portanto, não constitui surpresa. Há decerto, alguns planos longos, mas o esforço em direção a um registro subjetivo dá-se por outros meios.

Nesse caso, o conceito de cinema poesia de Pasolini pode ser útil para compreender como se processa o direcionamento ao sujeito no filme. O cinema poesia baseia-se na possibilidade de adequação do discurso indireto livre - um recurso narrativo da literatura - ao filme. Há uma tentativa de imersão do diretor na mente de seu personagem com vistas à adoção, por parte do primeiro, da psicologia e também da linguagem de tal personagem. O discurso indireto livre pressupõe uma relação mais lateral com a personagem, o autor abandona o seu modo de enunciar em detrimento de uma reanimação da linguagem da personagem em questão. O monólogo interior, por sua vez (ainda segundo Pasolini), não precisa necessariamente exibir a diferença de linguagem, diferença fundamental para estabelecer uma distância entre a visão de mundo do autor e a da personagem. De todo o modo, o monólogo interior pressupõe um "eu" como sujeito gramatical do discurso, ou seja, a imersão passa pelo uso da primeira pessoa. No cinema, por mais que haja uma primeira pessoa que narre linguisticamente, existe, quase sempre (exceto nos pouquíssimos casos de uso de câmera subjetiva sistemática), uma outra instância narrativa constituída pelo sujeito enunciador da imagem.

Por conta destas peculiaridades o discurso indireto livre no cinema deve ser (como acontecia na literatura burguesa) um pretexto para o autor oferecer uma diferenciada interpretação do mundo. Não é possível, de fato, que o cineasta reavive o discurso do personagem, pois aqui a diferença entre o texto escrito e a narração cinematográfica é determinante. No texto é possível reproduzir a linguagem de determinado grupo social através do uso de expressões idiomáticas, gírias, regionalismos e dialetos que criam a possibilidade de uma reavivação de um modo de

\footnotetext{
${ }^{1} \mathrm{O}$ mesmo acontece com a TV, que cada vez mais atribui concretude e significado à sua mediação, posicionando-se, muitas vezes, como metatevê. "Colocando em quadro, como dissemos, seu próprio processo de mediação, como se a realidade a ser apresentada fosse justamente aquela referente à interioridade do meio de comunicação, a metatevê parece sustentar que a linguagem dessa mídia não é apenas fenômeno mediador, mas experiência autêntica a ser vivenciada e desejada." (SERELLE, 2008, p.4-5).
} 
falar presente na realidade empírico-factual. O filme, por sua vez, não tem como emular estes modos de enunciação, a não ser de forma precária, como bem exemplifica a apropriação da estética amadora (câmera tremendo, falta de foco, enquadramentos imprecisos) como forma de tentar trazer autenticidade e uma subjetividade mais marcada para a ficção cinematográfica. Estas diferenças nos modos de enunciação sugerem que o discurso indireto livre no cinema não pode ser linguístico, ele deve ser estilístico.

Em Paranoid Park o uso deste recurso mostra-se pela contraposição destacada entre dois modos de enunciação. Ambos, apesar das diferenças, negam constantemente a possibilidade de onipotência de qualquer instância enunciativa. Por um lado, há o registro mais afastado, uma descrição da vida de Alex por um ponto de vista privilegiado. Para marcar este afastamento e esta clareza parcial, Van Sant constrói cenas bem enquadradas com uma imagem clara e nítida. A nitidez, entretanto, não denota necessariamente clarividência, muitas vezes é negada ao espectador a possibilidade de vislumbrar ou compreender as ações que se passam frente à câmera. Em outros momentos, o quadro ressente-se da personagem ausente e esta ausência é usada como forma de negar a onividência, a câmera parada só pode capturar a totalidade do quadro que ela focaliza, nunca a totalidade da ação. Aceitar a distância entre a sua câmera e o protagonista e entre este e as outras personagens é um recurso utilizado por Van Sant como forma de quebrar a ilusão de transparência e constituir uma narração marcadamente subjetiva.

Por outro lado, o discurso indireto do personagem é acionado quando sobrevém outro tipo de enunciação. Esta enunciação conforma-se inicialmente na resolução da imagem, quando acionado este recurso surge uma imagem granulada e também muitas vezes desfocada e tremida, tributária da estética de vídeos caseiros consagrada no YouTube. Neste registro, Alex está bem mais próximo da câmera e também bem mais a vontade. A intimidade mostra-se marcadamente presente na última vez em que é acionado este recurso, quando Alex sorri para a câmera. A descontração episódica de uma personagem que vive entre a tensão e o entorpecimento sugere uma proximidade dos iguais. Não por acaso, sempre que entra este tipo de registro são focalizados os esqueitistas de perto, manobrando as pranchas, fazendo truques, enfim, completamente à vontade, como se quem carregasse a câmera fosse um deles. 

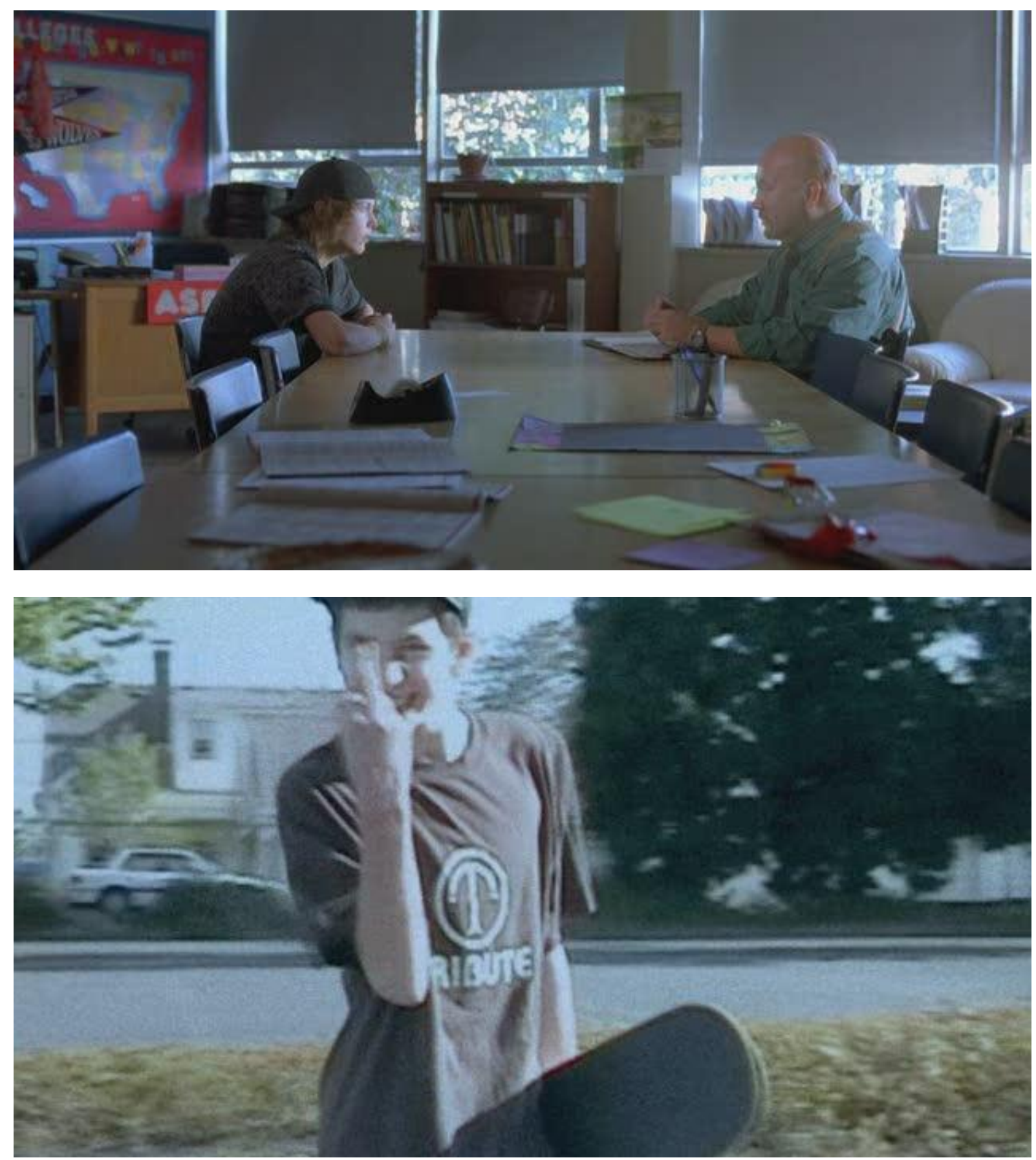

Figuras 1e 2 - Os dois tipos de discursos Fonte: still frame de Paranoid Park

Se a proximidade e a intimidade caracterizam o discurso indireto livre, será por seus opostos que se configura a narração em terceira pessoa propriamente dita. Alex, quando visto por este ponto de vista, está sempre distante. Distante das outras personagens, como na conversa com a mãe sobre o telefonema feito para a casa do tio 
na madrugada. Nesta conversa ouvimos antes a voz da mãe que demora a entrar no quadro e, mesmo quando surge, aparece ao fundo, desfocada e, finalmente, de costas. Também o pai é visto como um borrão, quase sem nitidez, como se estivesse em outro plano. Mesmo o sexo com a namorada parece alheio a Alex, e ela é vista também fora de foco.

Ao assumir a precariedade da narração em terceira pessoa Van Sant questiona a relação predatória entre sujeito e objeto que é fundamental e fundadora do realismo. Ousar tecer um quadro realista nos moldes modernos é, antes de tudo, crer no domínio do sujeito que vê sobre o objeto inerte. Para renovar o realismo cinematográfico, o diretor opta por uma relação de interafetação mútua entre objeto e sujeito que, não por acaso, é típica do momento pós-moderno. O protagonista, portanto, está sempre um pouco além ou um pouco aquém da câmera, mesmo em foco, ele permanece como uma entidade espectral que não se envolve com as outras personagens.

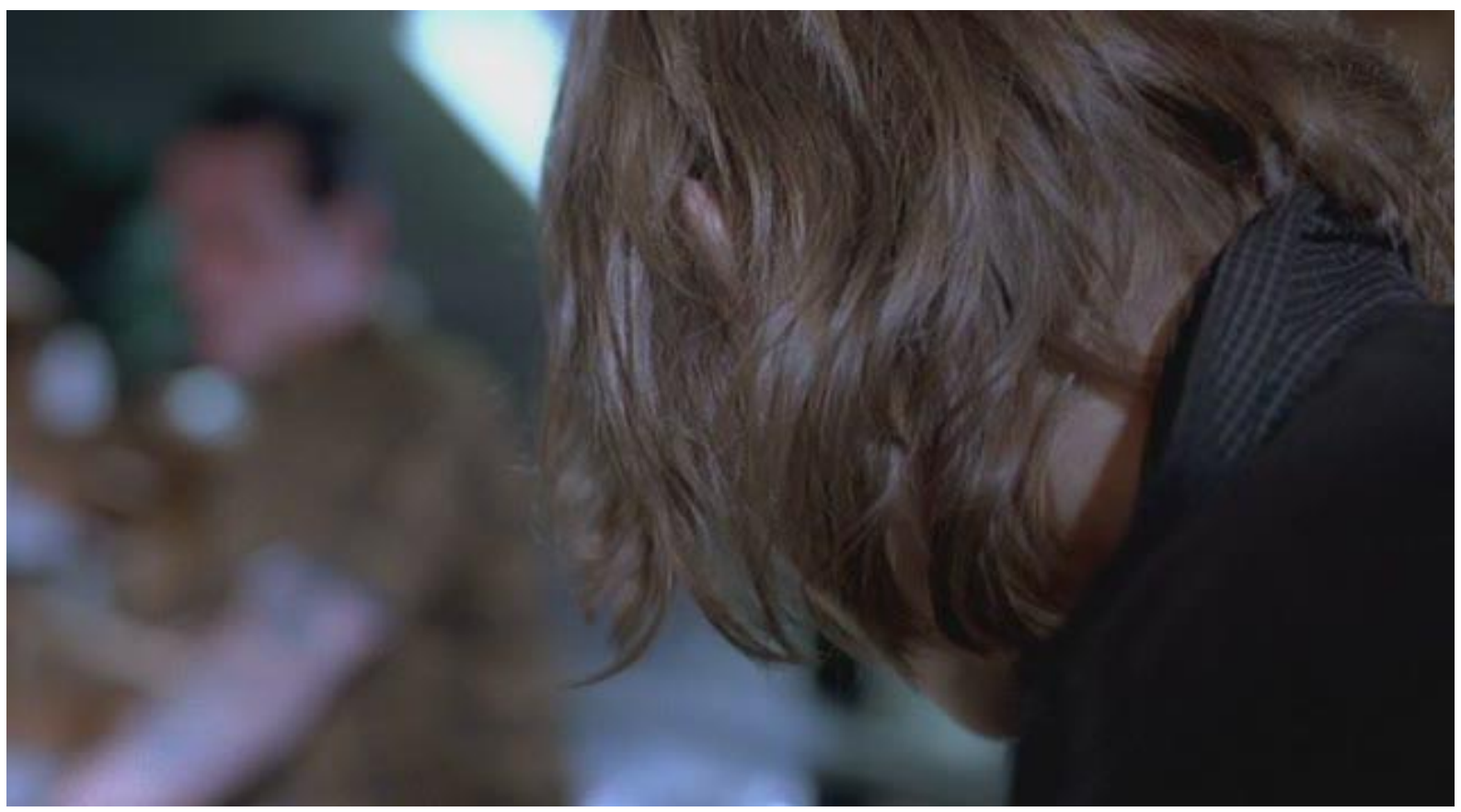



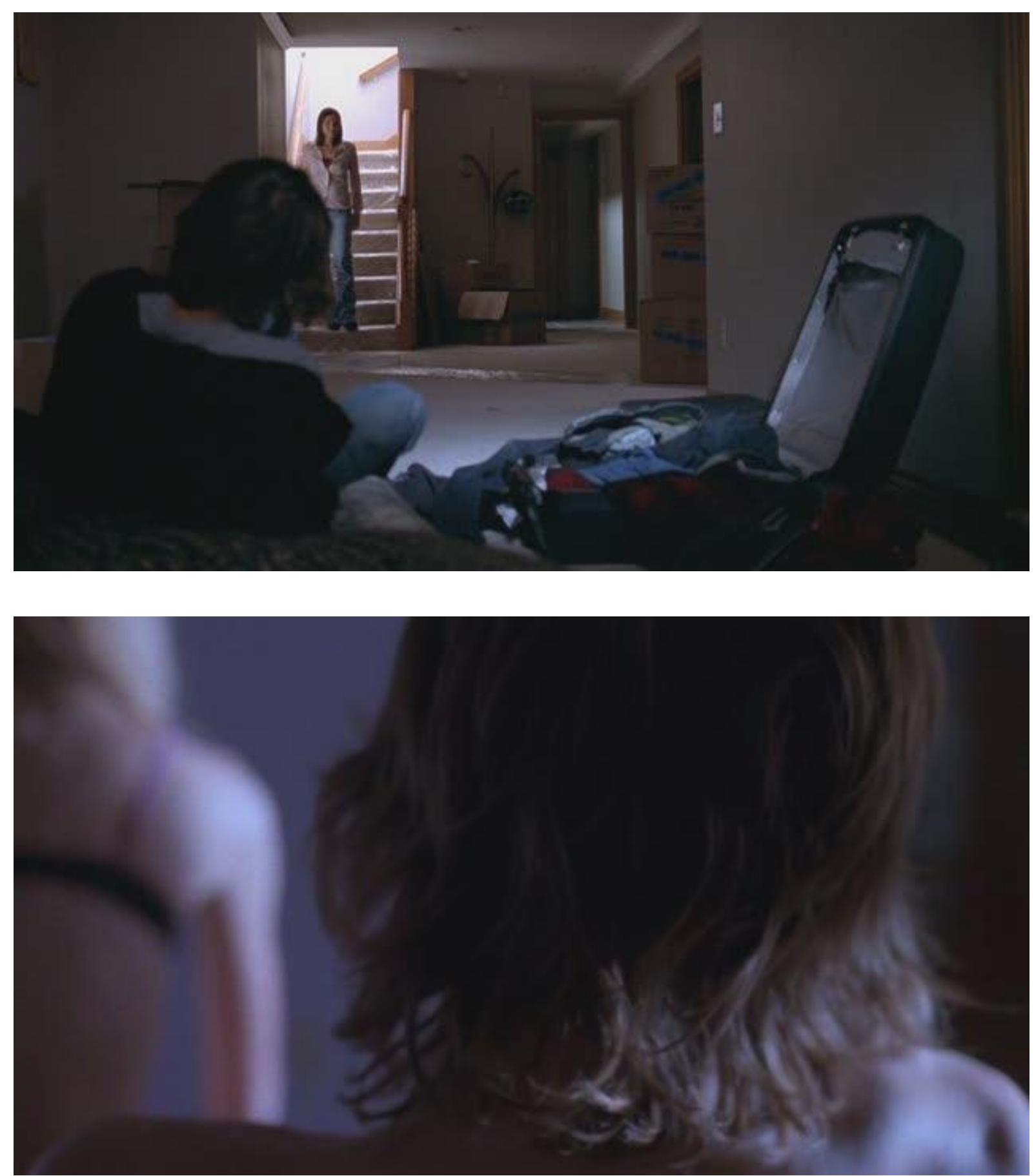

Figura 3, 4 e 5 - Visão do pai, do sexo com a namorada e da mãe Fonte: still frames de Paranoid Park

Quando sozinho, Alex não é mais apreensível pela câmera. Sucedem-se alguns planos longos com pouca ação que não seu caminhar lento. Outras vezes, ele é filmado de costas, negando aos espectadores a face do protagonista. O ritmo lento, cadenciado e pouco revelador da narração parece se referir a um estado de entorpecimento que cerca a vida de Alex. O cinza e a constante garoa da cidade de Portland intensificam este 
efeito de melancolia e tédio, no qual os eventos são quase indistinguíveis em termos de intensidade sensível. Nem mesmo o crime, acidental, mas ainda brutal, merece uma atenção demorada na narrativa do filme, como se a vida de Alex fosse mesmo como o vai e vem dos esqueites, um movimento sem direção definida, apenas a repetição constante. Há, eventualmente, manobras mais arriscadas, vez por outra acontece algo diverso na vida dele, mas que jamais quebra o fluxo de acontecimentos que marca o ritmo constante e tedioso da vida adolescente. No mundo adolescente de Alex a vida tem algo de irreal e para marcar esta irrealidade o diretor insere sons e ruídos durante alguns dos diálogos como modo de criar uma cortina entre ele e as outras pessoas. Este enublamento do mundo exterior ao personagem reflete também a confusão mental do protagonista diante do crime que sombreia sua vida. Também emulando este estado de confusão, entra o voice-over do protagonista que corresponde ao registro de seu diário. O tom inconclusivo, fragmentado e cronologicamente confuso do diário dá a estrutura da apresentação do enredo no filme. Como seu caminhar pelos corredores da escola ou pela orla, não parece haver uma direção e um propósito definidos.

O caráter marcadamente subjetivo da narração do filme surge também destacado quando ocorre o choque entre duas instâncias enunciativas, neste caso, entre voice-over e as imagens. Esta oposição é vista quando Alex vai para a casa de seu amigo Jared trocar de roupa e tomar banho. O depoimento em voice-over diz que a troca de roupa e o banho são motivados pelo suor, mas enquanto entra sua fala, ele é mostrado jogando a roupa em um saco de lixo e se escondendo de algo que espreita a casa. O conflito encenado de relatos destaca o caráter limitado de qualquer ponto de vista. As imagens que confrontam a fala nos lembram da precariedade inerente a qualquer testemunho, mas mesmo a aparente objetividade da câmera pode ser questionada, pois, no cinema poesia, como professa Deleuze, "a narrativa não se refere mais a um ideal de verdade a constituir sua veracidade, mas torna-se uma 'pseudo-narrativa', um poema, uma narrativa que simula ou antes uma simulação de narrativa.” (1997: 181).

A narração em terceira pessoa não adquire uma aparência de onisciência graças à estrutura narrativa do filme que, para destacar a sua incapacidade em relatar plenamente a vida de Alex, usa até da repetição de sequências. Deste modo, a primeira conversa com Jared sobre o parque e a pista é repetida como modo de reforçar o processo rememorativo da escrita de um diário. A restrição autoimposta da câmera é 
ainda mais marcante quando a mesma ação é mostrada por duas perspectivas. Assim, a já citada sequência que cobre as ações prévias ao banho, o próprio banho e o telefonema feito na casa de Jared é repetida com adição de novos fragmentos deixados de lado pelas elipses temporais. Ao destacar o que ficou de fora, o filme desnaturaliza a projeção cinematográfica realçando como a montagem de um filme escolhe pedaços de uma vida (mesmo que ficcional) que se desenvolve para além do que é mostrado. No caso desta repetição com diferença, alguns detalhes que pareciam desconexos ou casuais como a ligação feita após o banho são esclarecidos. Na primeira vez em que é mostrado este telefonema, não sabemos para quem e porque Alex está ligando. Depois, graças às informações dadas pelo próprio Alex e pelo desenvolvimento da trama, entendemos que a ligação foi feita para seu pai que estava na casa do tio, logo depois do crime, quando Alex procura um interlocutor para confessar sua ação (interlocutor transmutado em leitor fictício de uma carta que, já no fim do filme, descobrimos que corresponde ao diário lido em voice-over).

A resistência à onisciência pode ser vista também através do uso de formas paralelas de se referir ao grande evento da trama e de metáforas visuais como forma de propor um diálogo algo lírico com o espectador. O envolvimento de Alex no crime, deste modo, não é mostrado diretamente senão no fim do filme, mas antes podemos quase ver o fardo que ele carrega. Se na narrativa a confissão só ocorre para o interlocutor fictício de sua longa carta, nós espectadores assistimos pela sua reação ao crime relatado no noticiário uma confissão indireta de sua culpa. As metáforas visuais também primam pela delicadeza, o corredor da escola como limbo onde nada acontece remete à vida adolescente, um espaço de passagem entre a infância e maturidade em que Alex flutua quase como uma entidade etérea.

Um pouco menos sutil é o uso dos túneis como metáfora para a possibilidade de salvação. Acionado o discurso indireto livre pela imagem granulada e próxima, a visão dos esqueitistas lentamente se dirigindo à luz parece se referir a um modo de Alex articular sua saída. A sequência, inserida logo depois do banho pós-crime, enquanto ele está deitado na cama, parece sugerir uma escapatória. Os ruídos que acompanham o banho (sugerindo confusão e desespero) são substituídos pela trilha incidental e o calmo barulho das pranchas. Entretanto, o último esqueitista mostrado na sequência parece estar preso, ele ainda enxerga a luz, mas as saídas em ambos os lados estão vedadas por 
grades. A sensação de impotência fica ainda mais patente pelo voice-over que marca a volta ao registro em terceira pessoa. Focalizado em close-up ainda deitado na cama, como se já desperto de sua divagação pelo universo paralelo dos esqueitistas, Alex fazse ouvir pensando sobre a sua situação perante o crime e tentando buscar um ouvinte para tirar o peso dos seus ombros. Sua primeira ideia é ligar para o pai e a ligação, agora mostrada pela segunda vez, adquire uma significação mais clara. O pai, todavia, não pode ser alcançado.

A saída de Alex virá na escrita da longa carta, somente depois de escrevê-la e queimá-la ritualisticamente em uma fogueira como forma de expiar seus pecados, ele pode mover-se para frente. A sua escapada da situação, mais uma vez, vai ser metaforizada. Para se libertar do peso, ele vai precisar de ajuda, não dos seus amigos esqueitistas, mas da amiga Macy. Portanto, será também agarrado à sua bicicleta, fazendo da força dos pedais a origem de seu movimento que Alex pode seguir em frente. Somente quando ele se abre, confia em alguém, é que ele pode superar seu tormento. Logo após a carona Macy sugere a Alex (ainda que sem saber do crime acidental) a escrita da carta como forma de desabafo.

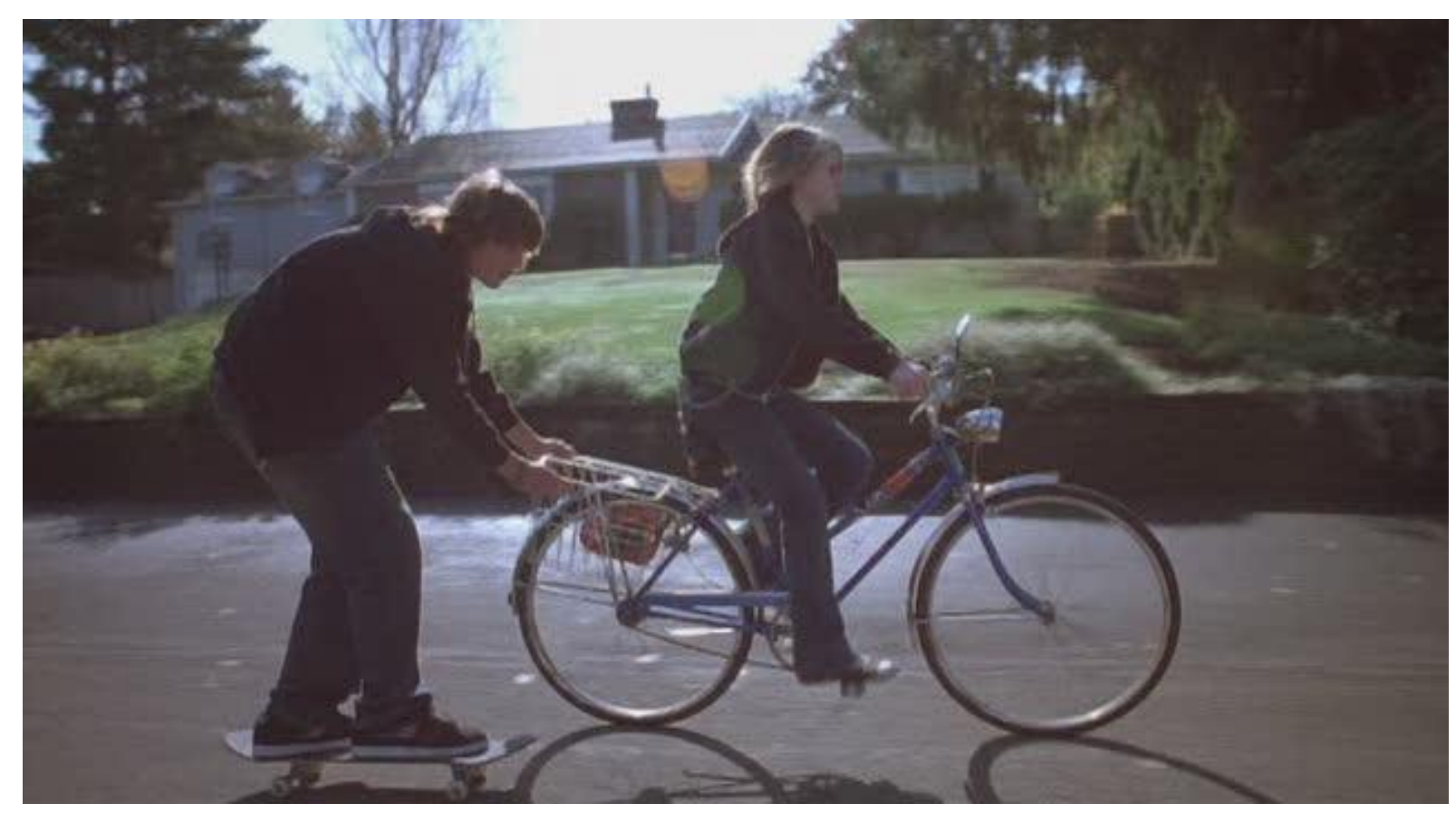

Figura 6 - Carona na bicicleta

Fonte: still frame de Paranoid Park 
O cinema poesia de Van Sant está a serviço de um enredo simples. Mais importante que a trama é o retrato social que se procura fazer de um microcosmo que não é o do diretor, nem em termos socioeconômicos, nem geracional. Vem à tona uma juventude pós-utopista, sem sonhos e nem grandes pretensões que se entrega ao fluxo da vida. Neste mundo, a pista de esqueite ocupa a função de local de encontro e interação, ela abre-se para as atuações, conflitos e exibições do corpo social. Neste mundo fechado o movimento das pranchas com seu ir e vir contínuo reflete o distanciamento com o mundo exterior, movimenta-se de todas as maneiras, mas sempre dentro do espaço conformado do grupo social.

A pista recupera a função metonímica dos objetos cinematográficos, ela não se refere a uma pista em especial, mas a todo um microcosmo. Este microcosmo é formado por jovens adolescentes de classe baixa, presos a uma vida sem maiores perspectivas de emoção que aquelas oriundas das manobras de esqueite. Em torno deste pequeno mundo giram também as pretensões dos participantes do grupo, entre eles Alex. Dentro do seu universo, a visita ao parque constitui seu programa predileto, embora mesmo ali ele aja como um observador de sua própria vida. Sua recusa em efetivamente manobrar o esqueite, o medo de se expor perante aos membros mais experientes, realça o caráter fantasmático de sua existência.

Alijado de si mesmo ele encontra abrigo no espaço marginal da pista construída ilegalmente dentro do parque por uma série de figuras marginais (guitarristas, punks, esqueitistas, bêbados, abandonados, vindos de famílias desestruturadas). Escondida nos confins da cidade, ela é um espaço separado da vida e da realidade, um mundo paralelo. Entretanto, por mais que se identifique com os frequentadores do local, Alex não deixa de ser um estrangeiro, ele não tem uma história triste e marginal, não é abandonado ou punk. Pelo contrário, faz parte da classe média dos subúrbios, sua família é nada menos que tipicamente média.

A duplicação de Van Sant, mesmo alegórica, mantém sempre a realidade empírico-factual à vista e ainda que ele problematize o preceito de transparência da imagem técnica, sua proposta é ela mesma uma tentativa de renovação do falar do real, um falar derivado para a subjetividade e que destaca a opacidade, mais que ainda assim procura constituir na mímesis um modo metafórico de acessar a verdade. A verdade 
nuançada do discurso subjetivo e algo poético prescinde da violência da asserção que marca os outros realismos aventados. A meia luz de Van Sant remete primordialmente à verdade possível na obra de arte, encarnando em seus modos de enunciação e narração os conceitos de terra e mundo (HEIDEGGER, 2007). Quando submetido a um olhar escrutinador Paranoid Park se retrai em seu mundo de significações revelando a parte oculta e obscura da obra que nunca pode ser totalmente aclarada. Como nos modos mais marcadamente autobiográficos, a defesa contra a fabulação ou irrealização do mundo entrincheira-se no discurso de verdade do sujeito que é, por sua natureza, igualmente revelador e ocultador. Com sua miríade de recursos narrativos e a tentativa de alternar as instâncias enunciativas o filme valoriza o potencial da ficção como caminho paralelo à verdade. Esta verdade fala tanto do mundo extradiegético quanto fortalece o estatuto do fictício, recuperando o valor do fingimento ficcional, mentindo para além do que é, mas sem se enredar em seu próprio universo fantasioso.

Referências bibliográficas

DELEUZE, Gilles. A imagem-tempo. Cinema 2. São Paulo: Brasiliense, 2007.

HEIDEGGER, Martin. A origem da obra de arte. In: MOOSBURGER, Laura de Borba. "A origem da obra de arte" de Martin Heidegger: Tradução, comentário, notas. 2007, 158p. Dissertação (Mestrado em filosofia) - Universidade Federal do Paraná, Curitiba.

PASOLINI, Pier Paolo. Heretical empirism. Washington: New Academia, 2005.

SARLO, Beatriz. Tempo passado. Cultura da memória e guinada subjetiva. São Paulo: Companhia das Letras, Belo Horizonte: Editora UFMG, 2007.

Metatevê: A mediação como realidade apreensível. Compós, 2008. Disponível em: http://www.compos.org.br/data/biblioteca 328.pdf. Consultado em: 10-11-2009.

Referências cinematográficas

PARANOID PARK. Direção: Gus Van Sant. Produção: Marin Karmitz, Neil Kopp, David Allan Cress. Intérpretes: Gabe Nevins; Daniel Liu; Jake Miller; Taylor Momsen e outros. Roteiro: Gus Van Sant. MK2 Productions, Meno films, 2007. 1 DVD (85 min), widescreen, color. Baseado na novela "Paranoid Park" de Blake Nelson. 